\title{
Influence of Air Pollution on the Deterioration of Monuments and Museum Collections
}

\author{
Raed Alghazawi \\ Department of Cultural Resources Management, Queen Rania Institute for Tourism and Heritage, The Hashemite University, Zarqa \\ 330127, Jordan
}

\begin{abstract}
The time has come to recognize the extreme importance of the archaeological sites in Jordan. They provide a wealth evidence and precise information regarding ancient civilizations and cultures. The safeguarding of this cultural heritage is one of the most urgent priorities, that involve the proper conservation and preservation methods of all artifacts and buildings that have an important artistic and historic value. Conservation is a whole field in regarding the care and treatment of valuable artifacts, both movable and immovable. It has two aspects: (1) the control of the environment - to minimize the decay of artifacts and materials and (2) the treatment of these-in order to stop or slow down any deterioration and to stabilize them where possible against further dilapidation. The museum environment is a limited space dedicated not only to exhibition but also to the appropriate conservation of works of art. This article presents an overview of the types of damage and deterioration that air pollution causes to indoor cultural heritage materials and monuments. It identifies the main damaging air pollutants from outdoor sources to be sulphur dioxide, nitrogen dioxide, ozone and sulphide gases.
\end{abstract}

Key words: Air pollution, cultural heritage, deterioration, museum.

\section{Introduction}

For a long time, there has been a large interest in the indoor air quality and its effect on human health and materials. It is well known that high levels of air pollutants such as trace gases and particles can harm human health and have detrimental effects on materials [1-3].

Air pollution as a general term means that there are unexpectedly some particles pollutants with high concentration, which occurs almost everywhere and has long history [4]. Also, it is well known that natural stones are considered as the most durable building materials through ages [5].

Efforts to evaluate indoor conditions have progressed from defining areas of interest to making measurements of potentially harmful agents and more recently, to the modeling of expected pollution levels.

Thus, weathering and deterioration of cultural

Corresponding author: Raed Alghazawi, assistant professor, main research field: museum environment. E-mail: ghzawi@yahoo.com. monuments and museum objects became natural process particularly near urban and industrial areas owing to air pollution, which if can't be stopped, it has to be slow down. Otherwise, humans will not have any cultural heritage to preserve in the future [6-8].

\section{Aim of the Study}

In this part, the different components and chemical characteristics of ambient air in Amman Citadel Mountain were studied according to national and international standards through realizing several statistical and analytical studies of all industrial activities in Jordan. One can say that the different values of air pollution were increased as a direct result of great development and wide using of energy which lead to presences of negative effects on air quality [9].

\section{Justification}

Jordan archaeological museum and the castle mountain in general contain important collections that require a controlled indoor environment to ensure 
their preservation and minimize their deterioration. In absence of a controlled indoor environment, these objects would be in great danger. Thus, museums must provide at least the minimum requirements for keeping and preserving objects in their current shapes and conditions. Therefore, it seems important to conduct an inclusive study to cater to the needs of the museum and have it improved and developed in order to portray the best possible image of the Jordanian legacy.

\section{Location}

The Hill of the Citadel (Jabal al-Qal'a) in the middle of Amman was occupied as early as the Neolithic period, and fortified during the Bronze age (1800 BC). The ruins on the hill today are Roman through early islamic (Fig. 1). The name "Amman" comes from "Rabbath Ammon" or "Great City of the Ammonites" who settled in the region sometime after 1200 BC. The bible records that king David captured the city in the early 10th century BC. Uriah the Hittite, husband of King David's paramour bathsheba was killed here after the king ordered him to the front line of battle [10].

In ancient times, Amman with its surrounding region was successively ruled by the then-superpowers of the Middle East: Assyria (8th century BC), Babylonia (6th century), the Ptolemy's, the Seleucids (third century BC), Rome (1st century BC) and the Umayyad (7th century AD). Renamed "Philadelphia" after himself by Ptolemy II Philadelphus, the city was incorporated into Pompey (the province of Syria) and later into the province of Arabia created by Trajan (106 AD). As the southernmost city of the Decapolis, Philadelphia prospered during imperial times due to its advantageous location alongside Trajan's new trade and administrative road-the Via Nova Trajana (Fig. 2) [11].

When Transjordan passed into Arab rule in the 7th century $A D$, its Umayyad rulers restored the city's original name of Amman. Neglected under the Abbasids and abandoned by the Mamlukes, the city's fortunes did not revive until the late 19th century-under the Ottoman Empire. Amman became the capital of the Emirate of Transjordan in 1921 and the newly-created Hashemite Kingdom of Jordan in 1947. Greater Amman (the core city plus suburbs) today remains by far the most important urban area in Jordan, containing over half of the country's population or about 3 million out of 5 million people [12].

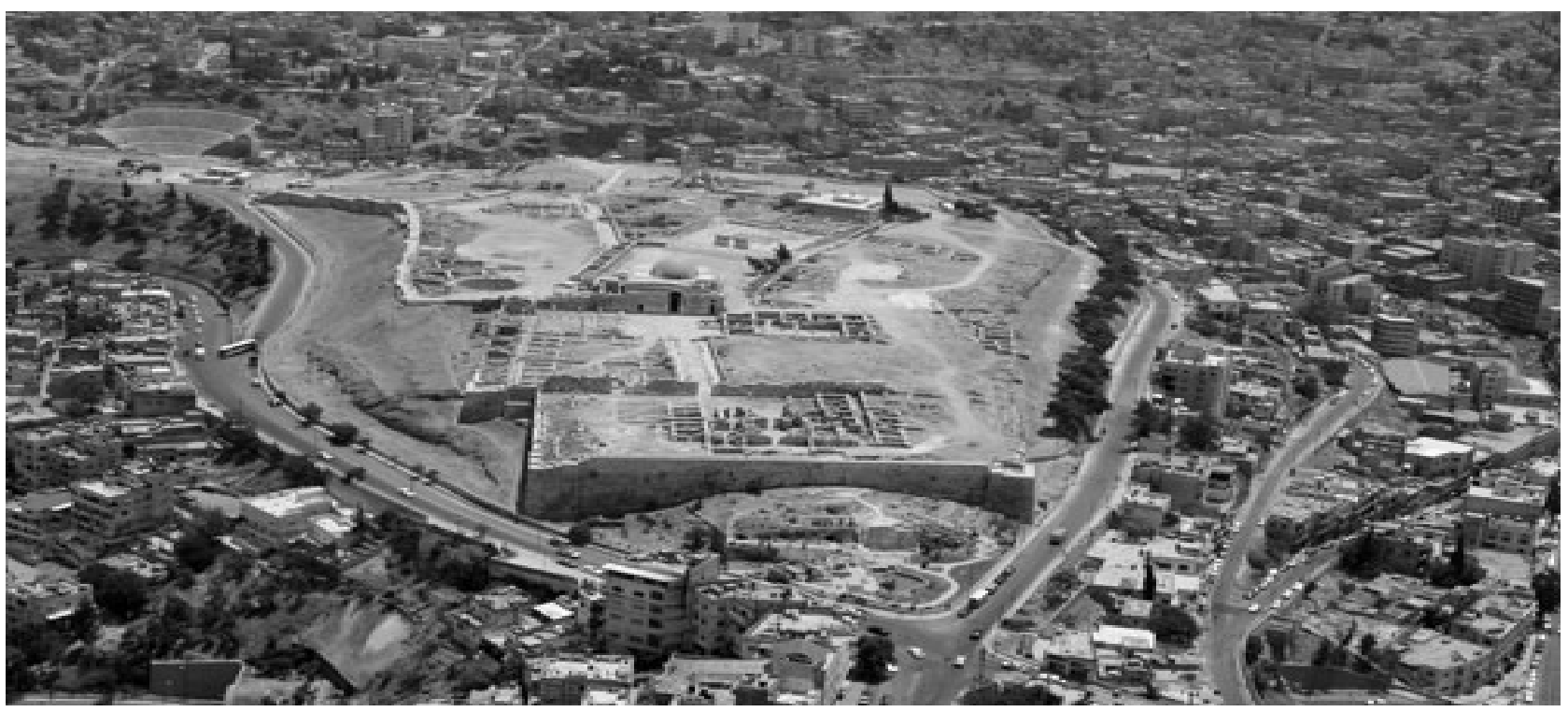

Fig. 1 Amman citadel. 


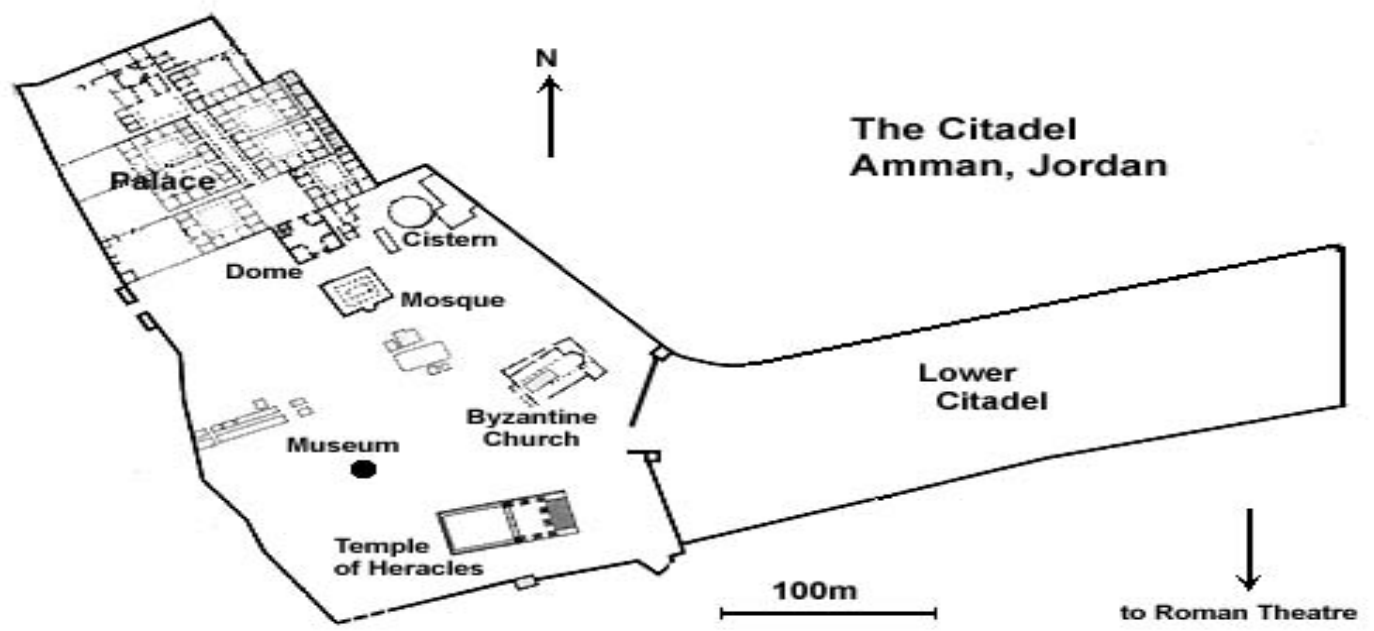

Fig. 2 Map of the Amman citadel.

\section{Materials}

The correlation between air pollution and museum objects may not be easy. In preservation, environments are a number of environmental factors, which can cause the degradation of material and artifacts. Among these gaseous, pollutants are the most destructive element. Gaseous pollution today is caused primarily by the burning of fuels in power plants, factories, commercial and domestic buildings and automobiles. The two main types of gaseous urban air pollution can be classified either as acidic or oxidizing. Over the years, these two types have merged and now the three main pollutants gaseous found throughout the industrialized world are sulphur dioxide $\left(\mathrm{SO}_{2}\right)$, nitrogen dioxide $\left(\mathrm{NO}_{2}\right)$ and ozone $\left(\mathrm{O}_{3}\right)$ [3].

\subsection{Sulphur Dioxide}

There is a general consensus that the chemical degradation of natural, calcareous building stone in polluted urban environments is predominantly due to the conversion of calcite to gypsum. The sulphation reaction can be represented in a simplified form [13].

$$
\begin{gathered}
\mathrm{CaCO}_{3}+\mathrm{SO}_{2}+2 \mathrm{H}_{2} \mathrm{O}+1 / 2 \mathrm{O}_{2} \Leftrightarrow \\
\mathrm{CaSO}_{4} \cdot 2 \mathrm{H}_{2} \mathrm{O}+\mathrm{CO}_{2}
\end{gathered}
$$

The initial and end products are well known but little known about the intermediate steps. Fassina [5] has suggested three possible routes in this process depending on different atmospheric conditions. Probably, the most important process is the heterogeneous oxidation of $\mathrm{SO}_{2}$ in the aqueous phase, which occurs in the atmosphere or on the stone surface. According to others, the prevailing mechanism is related to dissolution of $\mathrm{SO}_{2}$ in bulk water, present in the stone as condensation in the capillaries or absorbed by hygroscopic salts. Catalysts for this latter reaction can be found in soot and dust in the form of transition metal impurities such as Fe-compounds and Mn-compounds. Dry deposition of $\mathrm{SO}_{2}$ was found to be the dominant input mechanism in urban areas. The amount of aerosol sulphur which is deposited on vertical sheltered stone surfaces is small in comparison with the contribution of gaseous sulphur. Other studies have shown that there may well be a significant contribution of the deposition of $\mathrm{CaSO}_{4}$ from the atmosphere to large gypsum accumulations in more or less pure silicate sandstone [5]. These latter observations, together with the manifestation of gypsum layers even on bronze and glass surfaces, confirm that the gypsum constituting the deterioration layer does not always completely originate from the underlying rock [14].

The far more soluble gypsum (2.4 g/L), compared 
to calcite $(0.014 \mathrm{~g} / \mathrm{L})$, is easily washed away from stone surfaces, which are directly exposed to rainfall. In places sheltered from rain, dirt can accumulate as incrustations strongly bound to the surface with $\mathrm{CaCO}_{3}$ and $\mathrm{CaSO}_{4}$. The chemical composition and physical properties of the crust are different from the rest of the stone-higher density, lower permeability to water and total or partial substitution of $\mathrm{CaCO}_{3}$ by $\mathrm{CaSO}_{4}$. These differences speed up the decay of the stone, because of [15]:

- Variations in volume: gypsum has a greater volume than the calcite replaces and its generation in cracks and pores at the surface is accompanied by expansive stresses;

- The difference in thermal expansion of the gypsum and the calcite. This difference is further emphasized by the black top layer, caused by fumes and carbonaceous particles, which tend to absorb a larger amount of radiation than white surfaces;

- The reduction of permeability, which will increase water retention and all the corresponding adverse effects.

On masonry materials such as many types of sandstone, granite and brick, dry deposition tends to produce a thin black accumulation. Both laboratory and field studies have shown correlations between the amount of this soiling and the dry deposition of sulphur oxides. It is important to discriminate between the effects of $\mathrm{SO}_{2}$ and acid rain, since sulphur dioxide comes from local sources while acid rain is the result of long-range transport and chemical transformation of $\mathrm{SO}_{2}$ from distant sources [3].

\subsection{Nitrogen Dioxide}

The oxides of nitrogen contribute a significant amount of the total loading of air pollution and of acid rain. However, their reaction products do not seem to be present on carbonate stone to the same degree as those of $\mathrm{SO}_{2}$. The existence of biological sources of nitrate further complicates the relation between atmospheric $\mathrm{NO}_{\mathrm{x}}$ levels and the occurrence of nitrates on exposed stone surfaces. The difficulty in finding calcium nitrate crystals on exposed stone surfaces is probably due to its very high solubility $(2,660 \mathrm{~g} / \mathrm{L}$ for $\left.\mathrm{Ca}\left(\mathrm{NO}_{3}\right)_{2} \cdot 4 \mathrm{H}_{2} \mathrm{O}\right)$ in water and its hygroscopic nature. $\mathrm{NO}_{2}$ drastically increases the corrosion rate (indicated by weight gain) of calcareous stones in $\mathrm{SO}_{2}$-containing atmospheres at high (90\%), but not at low (50\%) relative humidity. Based on laboratory exposure of calcite powders, it has been proven that $\mathrm{NO}_{2}$ acts as a catalyst for oxidation of S(IV) to S(VI) at a pure calcite surface, in the presence of molecular oxygen at humid conditions (RH: 90\%). Extensive field and laboratory exposure of marble also showed that the corrosion due to nitrates and that caused by sulphates are in the same order of magnitude. Nitrate enrichment on different calcareous stone types (marble, limestone and sandstone) was found to originate mainly from deposition of gaseous $\mathrm{HNO}_{3}$ and to a lesser extent to dry deposition of $\mathrm{NO}_{2}$. Because of their high solubility, nitrate salts are transported into the inner part of the stone, where they undergo phase transformations such as crystallization and hydration, depending on the ambient conditions (temperature and relative humidity). This may cause micro cracks in the stone structure and hence, accelerate deterioration [16].

\subsection{Ozone}

During the past decade, there has been a growing concern about the changes in urban air quality [17]. Ozone is a very reactive gas. Troposphenc ozone causes negative health effects in humans and can deteriorate valuable materials [18-20]. It is 100 times or more fast than the catalytic action of iron and manganese with $\mathrm{O}_{2}$ [21].

Ozone is produced in the stratosphere at a height of 20-30 $\mathrm{km}$ by the action of UV radiation on oxygen. The UV concerned here is of much shorter wavelength than ever penetrates to the surface of the earth [3].

A complementary issue is the effect on building materials particularly in their deterioration and 
maintenance arising from pollution. Presently, those concerns relate specifically to the rise of pollution from vehicles [17].

Ozone does not play a direct role in the deterioration of limestone, but it is important in its strong oxidizing agent. Ozone has been shown to accelerate the sulphate formation at a calcite surface in an $\mathrm{SO}_{2}$ atmosphere under both humid and dry conditions [21].

Methodology:

The measurement took place in April 2012. It was part of an international pollution monitoring campaign undertaken by the "Accessible Heritage" project at University College London's Centre for Sustainable Heritage.
As part of the campaign, diffusion tubes to measure sulphur dioxide, nitrogen dioxide and ozone were received. These pollutants are generated outdoor, typically from motor vehicle's fuel combustion or industrial processes.

Two types of tubes were received-one with white and black caps for ozone and the other with white and green caps for sulphur dioxide and nitrogen dioxide simultaneously. Two tubes of each type were provided for reproducibility. The four tubes were exposed on the site (Fig. 3) for four weeks. They were then returned to University College London for analysis.

The tubes (Fig. 4) work by a process called molecular diffusion. The white cap of the tube filters out particles while the colored cap contains the

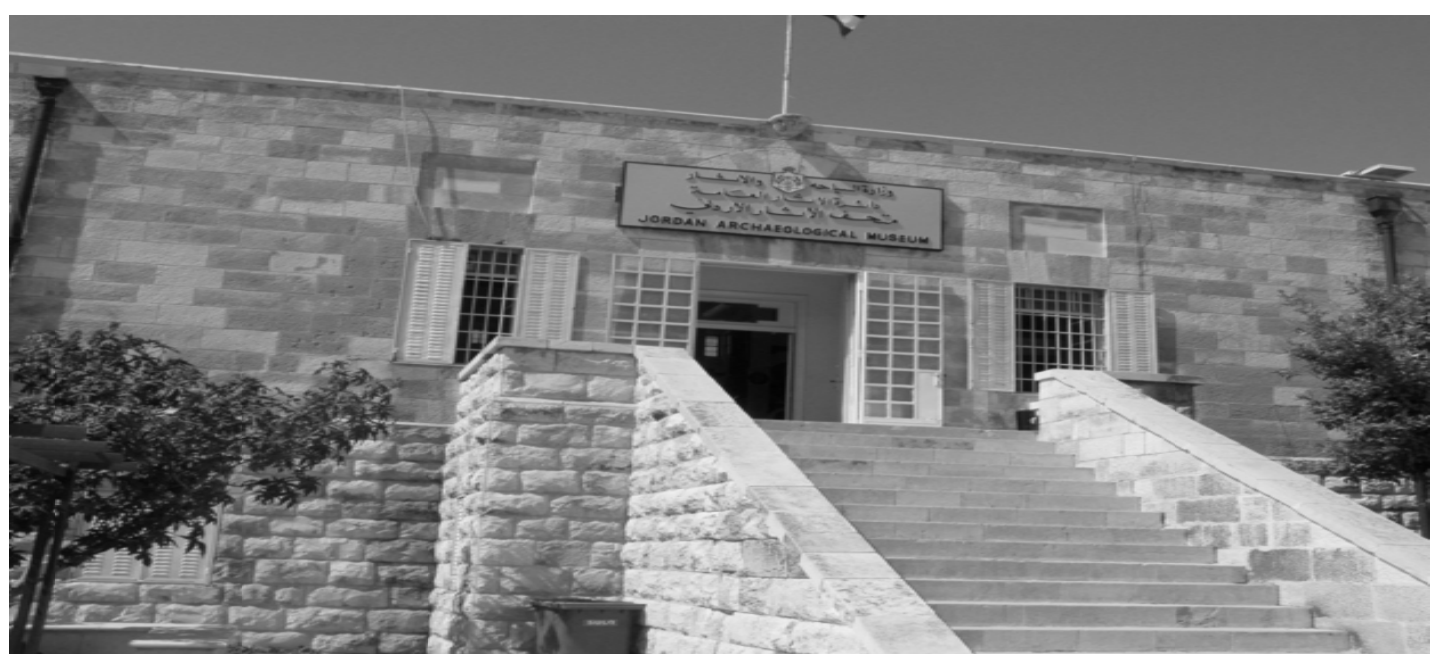

Fig. 3 Jordan archaeological museum (where the tubes were installed).

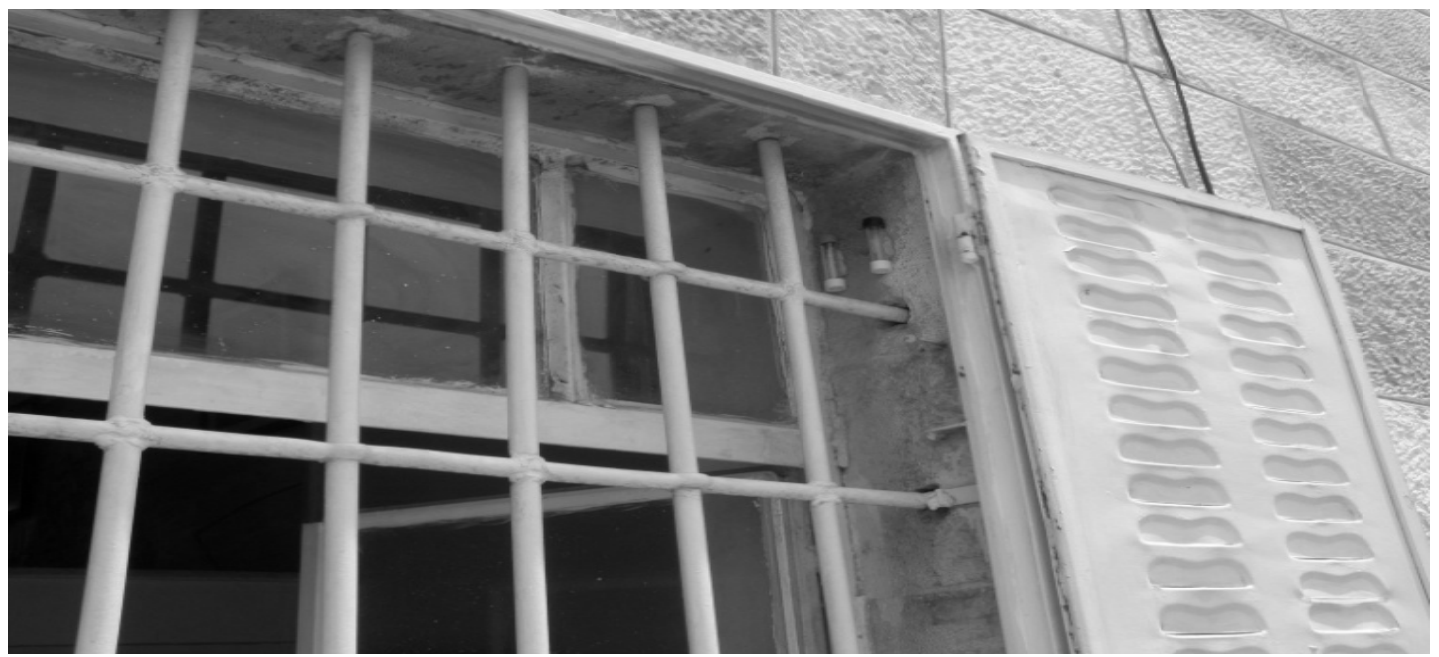

Fig. 4 The air quality monitoring tubes. 
absorbent required for a given compound. During molecular diffusion, compounds will move from an area of high concentration to an area of low concentration. The compounds in the air are at a higher concentration than those in the tube, so, the compounds diffuse into the tube and collect on the absorbent at the end of the tube. Because the compounds are absorbed, the low concentration in the tube is maintained and therefore, diffusion continues. The rate that the compounds move into the tube is called the uptake rate. This is a known rate and is used in the calculations during analysis. The tubes are clear as light is required during the absorption process. A technique called ion chromatography is used in the lab to determine the concentration of compounds on the tube. This is then used in a calculation with the uptake rate to calculate the average concentration of compounds that were present in the air over the monitoring period.

\section{Result}

For the Citadel Mountain, the averaged results in ppb (part per billion) are as follows:

(1) Ozone $\left(\mathrm{O}_{3}\right)$ : $30.58 \mathrm{ppb}$

(2) Sulphur dioxide $\left(\mathrm{SO}_{2}\right): 3.08 \mathrm{ppb}$;

(3) Nitrogen dioxide $\left(\mathrm{NO}_{2}\right): 18.75 \mathrm{ppb}$.

For a reference preservation target of 1 year, the maximal recommended guideline values of these 3 pollutants for indoor collection are as follows:

(1) Ozone $\left(\mathrm{O}_{3}\right): 5.0 \mathrm{ppb}$;

(2) Sulfur dioxide $\left(\mathrm{SO}_{2}\right)$ : $3.8 \mathrm{ppb}$;

(3) Nitrogen dioxide $\left(\mathrm{NO}_{2}\right)$ : $5.2 \mathrm{ppb}$.

Conversion tools can be used to estimate indoor values corresponding to these measurements.

\section{Conclusion}

This study was undertaken in order to assess air quality at Amman Citadel Mountain which represent the center of the capital of Jordan. Criteria air pollutants that were measured include the main damaging air pollutants from outdoor sources - sulphur dioxide, nitrogen dioxide, ozone and sulphide gases. Basic meteorological parameters were also measured. Findings indicate that most detected air pollutants where below their maximum corresponding national limits set by Jordanian ministry of environment. However, ground ozone was exhibited several incidences where it has exceeded maximum limits set by World Health Organization (WHO). High ozone values go in line with previously published modeling results which predict high values of ground ozone at the capital of Jordan city center. There is a great concern that ozone may expedite erosion and deterioration rates of rocks at the site. Therefore, a mitigation plan has to be strictly adopted in order to protect the treasures of historic sites in Jordan in general. Findings also indicate that westerly and northwesterly wind dominated wind site during this measurement campaign, which implies that the monitoring site and the city center are impacted by air pollutants that are originated somehow by the traffic jam at the nearby city center.

\section{References}

[1] National Ambient Air Quality Standards (NAAQS). 2002. "Evanston Public Library Strategic Plan, 2000-2010: A Decade of Outreach.” Evanston Public Library. Accessed July 19, 2008. http://www.epl.org/library/strategic-plan-00.html.

[2] Brimblecombe, P. 1988. "The Composition of Museum Atmospheres.” Atmospheric Environment 24 (1): 1-8.

[3] Thomson, G. 1986. The Museum Environment, 2nd Edition. London: Butterworth.

[4] Brimblecombe, P. 2000. Air Composition Chemistry, 2nd Edition. England: Cambridge University Press.

[5] Fassina, V. 1988. "Environmental Pollution in Relation to Stone Decay." In Air Pollution and Conservation: Safeguarding Our Architectural Heritage, edited by Rosvall, J., and Aleby, S. Amsterdam, The Netherlands: Elsevier Science Publishers.

[6] Aslam, M. 1996. "Acid Deposition and Stone Decay, Recent Trend in Conservation of Art Heritage.” In Stone Conservation: An Overview Of Current Research, 127-152.

[7] Anderson, T. 1988. Deterioration of Architecture in Scandinavian Effects of Air Pollution on Stone, Air Pollution and Conservation-Safeguarding Our 
Architectural Heritage. Amsterdam: Elsevier.

[8] Santis, F. 1995. "Interaction of Acid Gaseous Atmospheric Pollutants with Carbonate Stones." In International Proceeding of Preservation and Restoration of Cultural Heritage, 335-347.

[9] Holzwalth, D. 1996. "Building Stone from Southern Palatinate (Western Side of Oberheingraben) and Their Petrographical and Geotechnical Properties.” In 8th International Congress of Deterioration and Conservation of Stone, 21-27.

[10] Al-Hassan, A. 1991. Air Pollution Monitoring in Amman. Amman, Jordan: Environmental Research Center.

[11] Al-Hazaymeh, N. 1994. "The Umayyad Palace on the Citadel-Amman.” M.A. thesis, Yarmouk University.

[12] Zyadin, F. 2004. Amman El-Kobra-Tarikh Wa Hadara, Amman. Jordan: Arabic Reference.

[13] Ghawanma, Y. 1979. Amman-Hadarateha Wa Tarikhha, Amman. Jordan: Arabic Reference.

[14] Torraca, G. 1982. Porous Building Material: Material Science for Architectural Conservation. Rome:
ICCROM.

[15] Cronyn, J. 1990. The Element of Archaeological Conservation. London: Routledge.

[16] Van, Grieken, R. 2010. "Identifying the Sources of Atmospheric Particles in Museum Environment." In COST D42 WG2 Meeting, 65-72.

[17] Massey, W. 1999. "The Effects of Ozone and $\mathrm{NO}_{\mathrm{x}}$ on the Deterioration of Calcareous Stone.” The Science of the Total Environment 227: 109-121.

[18] Miller, G. 2001. Tainted Air-Is Ozone Responsible for the Asthma Epidemic in Children? UK: New Scientist.

[19] Blades, N., Oreszczyn, T., Bordass, B., and Bordass, W. 2000. Guidelines on Pollution Control in Heritage Buildings. London: Museum of London Picture Library.

[20] Weschler, J., Shields, C., and Naik, V. 1989. "Indoor Ozone Exposures.” The Air and Waste Management Association 39 (12): 1562-1568.

[21] Martin, L. R. 1984. Kinetic Studies of Sulfite Oxidation in Aqueous Solutions, Acid Precipitation Series. London: Butterworth. 